\title{
The Effect of the Use of Teaching Kits for Single Phase as Tools and Teaching Aids
}

\author{
Jasman Bin Esmon \\ ${ }^{1}$ Jempol Community College, Malaysia
}

\begin{abstract}
The use of the Material-centered Teaching method by using the Teaching Kit Single Phase Electrical Wiring (KSPEW) is an innovation in the teaching process especially electrical wiring modules in community colleges. The purpose of this study was to develop a teaching kit for single phase and see to what extent the effectiveness of the use of KSPEW can help improve students interest towards the electrical wiring and assist instructors in teaching process. This study was carried out in Jempol Community College, Malaysia. The samples consist of 14 students of the Electrical Installation Certificate Program semester 1 and 4 teachers. To see the effectiveness and suitability of the KSPEW, the assessment made on the behavior of students who are divided in small groups during KSPEW activities carried out while the instrument is a set of questionnaire. Statistical analysis is used for the purpose of analyzing descriptive data and it using the Statistical Package For Social Science for Windows Release 20.0 (SPSS) in order to obtain the value of the frequency and percentage. Findings show that interest is at a high level and KSPEW can help educators in the teaching process. Besides that KSPEW produced shall be in force and modified again in order to enhance its effectiveness.
\end{abstract}

Keywords: Teaching Kit, Single Phase Electrical Wiring (KSPEW), Community College, electrical wiring modules, Electrical Installation Certificate

\section{The Purpose of the Study}

The purpose of this study was to develop a Teaching Kit single phase Electrical Wiring (KSPEW), as a tool and teaching materials. It is to facilitate application knowledge theory in learn by Electrical Installation Certificate Program students in single phase wiring module. In addition, it also heightens the interest of students towards the electrical wiring and thus can help instructors in teaching process.

\section{Background}

Education is a deliberate, systematic effort made by a community to deliver the knowledge, values, attitudes and skills to its members, develop individual potential and changes that occur in human (Ibrahim Mamat, 1993). A country is a developed country that education systems. The education system is the key factor to shape the identity of the nation, became the most important tool for the development of the country, serves as a solid intermediate to achieve unity and well-being of the nation and the country (Tajul Ariffin and Nor'aini, 1992). Currently, World Education has flourished with the expansion of various types of media in the presentation of information. A variety of teaching methods have been applied in the teaching and learning process. For example, the merger of teaching and learning techniques see, hear and implement would be to provide a better understanding of the learning process for students. Learning is an effort to acquire knowledge, seek knowledge (Mok, 2000). This is because learning is an ongoing process. The processes involved are as students got information from lecturers, make a written or practical training up to occur changes in the students. Gagne et. Al. (1976), learning as behavior change or the ability of a person who can be sustained, not including changes caused by the process of growth. Overall, learning means the process acquire the knowledge or skills through stimuli-reaction, resulting in a change in the behavior of a person. Such behavior is permanent and stable. Meaningful learning encompasses cognitive-conscious existing experience, understanding, learning initiatives and motif (Mok, 2000). Learning is very closely linked to teaching. Teaching aims to create learning. Teaching aims to create learning. Effectiveness of learning is dependent on the ability to use skills teaching that can facilitate learning. There are two teaching functions, namely stimulating learning and creating effective learning situation (Mok, 2000). For skills training institutions, an appropriate teaching method is crucial to facilitate the teaching and learning process occurs. There are a variety of ways used by each instructor to produce a process of teaching and effective teaching. One very important way is through the use of tools and teaching aids. Teaching aids and stimulation elicits the desire of students to know more about something and can also make learning process more interesting and effective. The use of tools, and educational resource materials and planned systematic manner will make education more meaningful and positive impact on the teaching and learning process. Therefore, the presentation of a teaching, use of appropriate teaching aids is especially important technical subjects. For example, technical subjects such as electrical engineering, practical learning, the use of simulation, job training (hands-on), project, problem-solving methods and examples of solutions that were important to improve students, understanding and experience.

\section{Statement of the Problem}

If seen to teaching and learning is now, a handful of trainers still tend to use the conventional method, namely, using the method of "Chalk and Talk" in which trainers in total be tutor to students with "Marker Pen" and "Whiteboard". Although these changes have to do with education we must recognize that technology. However, this method still popular especially among educators because this method is feasible without having to make long and complicated setup (Rudin Salinger, 1994). However, the student feels such learning

\section{Volume 4 Issue 12, December 2015}




\section{International Journal of Science and Research (IJSR) \\ ISSN (Online): 2319-7064}

Index Copernicus Value (2013): 6.14 | Impact Factor (2014): 5.611

environment makes them bored and tired because there is only one-way relationships, namely trainers submitting content and 18 students heard in a static and same at each session. This makes the learning interest of students to pursue the decreased. Usually, accompanied by critical thinking skills, convincing expression, and problem solving skills. The understanding is to use facts to information and systematic problem solving (Kamarudin Hj. Husin, 1990). On the basis of appropriate skills, students are able to generate a high level of understanding,. At the same time guiding students towards critical and creative-minded. The study of (Ahmad Rizal Madar, 2006), students are having trouble to capture the concept and skills in the subject of science. Among these problems is the reason to the lack of scientific knowledge and skills as well as less willing to engage in the activities characteristic of science in their daily lives. Therefore, there is no reconciliation between the requirements of students with cognitive growth concept. Then the science concepts that are applied are not achieved by students. Electric single phase Wiring topic is one of the topics that need to be taken by students who took Electrical Installation Certificate Program in Community College Malaysia. However, existing teaching methods used by trainers has yet to be able to change the students learning styles towards more effective. Because instructors are still commonly practiced teaching methods, students having trouble in understanding topics in Electrical Wiring Single Phase. This will slow down the process of teaching \& learning and makes it difficult for students understand the topic appearing in Single Phase Electrical Wiring at the higher level when they pursue higher education later.

\section{The following Study objectives}

The purpose of this study is to:

1) Develop teaching kits for Single Phase Electrical Installation Certificate Program for Community College Malaysia.

2)Produce teaching Kits single phase Electrical Wiring for Electrical Installation Certificate Program in the form of practical Community College Malaysia using learning theory approach Behaviorism.

3)Identifying students interest in the learning process for single phase by using a kit of teaching material.

4)Assist trainers conducting the teaching and learning process easier and more effective while in class.

\section{Methodology}

i) Overall review of the implementation of the development phase of this product is based on a design model ADDIE, ' analysis', 'design', 'development' ,'implementation' and ' evaluation '. Here below is the phases involved in designing this teaching kit:

\section{Analysis}

The development of the teaching kit have to identify the problems encountered and how to resolve it. Problems can be identified through interview, observation, surveys, questionnaires etc. After identifying the problems encountered, the teaching kit development should find the cause or factors that give rise to the problem. In addition, this analysis phase, aspects of the learning environment, analysis of users and learning objectives are identified. Development of the teaching kit will need to be assessed against the following:

a) The goal of the teaching kit

b) Teaching

c) Kit objective target group

d) The contents of the teaching kit

e) Pedagogical approach to the use of the kit

f) Strategies for teaching all this analysis, done to ensure systematic instructional design generated meet or meet the needs of users.

\section{Design}

The design phase is the process of transferring information from the analysis phase to one physical sketch that will be used during the process of construction. All the information requirements in this design process is taken from the initial analysis phase. In designing the teaching kit, the following should be noted:

a) Determine the content of the teaching kit based on content that has been developed in the phase analysis.

b)Determine the teaching and learning activities in accordance with the objectives of the construction of the teaching kit.

c) Determine the delivery method information understandable and appropriate to users.

d)Determine the display suitable design.

\section{Development of a teaching kit}

Development of the teaching kit involves the process of developing or producing teaching kits with the use of realistic accessories. Development of the teaching kits should be developed based on a predetermined design in the design phase.

\section{Implementation of the teaching kit}

This phase is used by developers of teaching kits to develop and implement a teaching kit. The main elements which have been designed in the previous phase must be realization. Work process in this phase are as follows:

a) Developing a teaching kit

b)Evaluate teaching kit.

c) Testing teaching kit

d)Modification and repair kit to repair and improve the quality of the teaching kit.

\section{Evaluation Phase}

This phase refers to the process of testing and evaluation of the teaching kits developed this test phase is the objective of the teaching kit has been achieved or not. According to Henry Ellington and Phil Race, (1994), to guarantee a system running smoothly and achieve its objective, the evaluation should be made.

\section{ii) Samples}

The samples used by researchers and it consists of 14 students from semester 1 and 4 teachers from Electrical Installation Certificate Program in Community College Jempol to test the effectiveness of KSPEW. For a sample of students, they are divided into 7 groups where each group

\section{Volume 4 Issue 12, December 2015}




\section{International Journal of Science and Research (IJSR) \\ ISSN (Online): 2319-7064}

Index Copernicus Value (2013): 6.14 | Impact Factor (2014): 5.611

contains 2 makes students. The study population as a whole was about 18 people, including instructors and students. Table 1 below shows the distribution of the samples.

\section{iii) Instrument}

Instrument in this study researcher will use the questionnaire to obtain the results of the findings. The use of the questionnaire allows researchers' access to information that many little expense (Mohd Majid Konting, 1994). In addition, it is a simple questionnaire method and easily administered. The proposed answer submitted will facilitate the respondents answer questions very quickly In this questionnaire methods, instructor who teaches single phase electrical wiring module will evaluate in terms of student collaboration within the Group and the suitability of the design of KSPEW. The questionnaire is divided into two parts, namely, part A and part B.

Table1: Part of the questionnaire items

\begin{tabular}{|c|c|c|c|}
\hline No. & Review Questions & Respondent & No. Items \\
\hline i & $\begin{array}{l}\text { Do 'KSPEW' can help attract the interest of students } \\
\text { in the teaching and leaming processes, particularly in } \\
\text { the module Wining? }\end{array}$ & Student's & $\begin{array}{c}6,7,8,9,10,11,12,13,14,1 \\
5\end{array}$ \\
\hline ii & $\begin{array}{l}\text { Do 'KSPEW' can assist instructors in teaching and } \\
\text { leaming processes? }\end{array}$ & Teachers & $\begin{array}{c}16,17,18,19,20,21,22,23 \\
, 24,25\end{array}$ \\
\hline
\end{tabular}

\section{iv) Pilot Study}

To ensure the validity and reliability of the instrument, a pilot study will be conducted. The pilot study provided an opportunity for the respondent to comment on the survey instruments (Mohd Majid Konting, 1994). Pilot study allows researchers to identify lack of questionnaire items and review instruments, thereby making some changes so as not to affect the findings (Mohd Majid Konting, 1994). From the pilot study carried out by researchers, found the Alpha value for this study was Krombach 0.840 .83 (students) and (trainers). In view of the value of the alpha for the study was more than 0.5 , then the reliability for the questionnaire for this study is high.

\section{Data Analysis}

\section{i) Do 'KSPEW' can help attract the interest of students in the teaching and learning processes, particularly in the module Wiring?}

This analysis is intended to find out whether the use of KSPEW in particular in the Electrical Wiring module single phase influences increase student interest. There are 10 items that are related in terms of interest. The highest percentage of "agree" is derived from the item numbers $6,7,8,11$ and 15 with each obtain $100 \%$. The items include a fun use of $\mathrm{KSPEW}$, design of KSPEW and to increase interest in and feel safe comfortable while performing activities of KSPEW. In addition, items numbers 10,12 , and 13 , have a percentage, from $86 \%$, and $93 \%$ of them agree that interest in the use of KSPEW is increasing after the use of KSPEW, activity of KSPEW in earnest and stimulation to use KSPEW also increased. Referring to the analysis of the study, the use of KSPEW can increase student interest in Electrical Wiring Single Phase.

\section{ii)Do ' $K S P E W$ ' can assist instructors in teaching and learning processes?}

This analysis is to find out whether a Kit of teaching material (KSPEW) helps educators in teaching Electric single phase Wiring in Electrical Installation Certificate Program. Most of the items on the question of this study to acquire a percentage of ' agree ' very high $100 \%$. The items is item number 16,17 , $18,19,20,21,23,24$ and 25 . Overall respondent agree that the items could help respondent save time, components used are appropriate to the subject taught, KSPEW in line with syllabus education module, KSPEW is effectively used as teaching aids and components easily available in the event of damage.

\section{Conclusions}

Aspects of this study is to identify the interest of students towards electric single phase wiring module during use of the teaching Kit material (KSPEW) in the Electrical Installation Certificate Program. The findings state that the interest of students towards electric single phase wiring modules are at a high level. The findings state that student interest aspect against the KSPEW are a high level which noted the $86 \%$ to $100 \%$. Almost the entire students assume that by using their sense of KSPEW interest Certificate Program, namely in the Electrical Installation module Electrical Wiring single phase increasing. The findings showed the majority of respondents are very fun and with the use of KSPEW. This is because they can give a boost and add the desire to perform the activities of KSPEW. Apart from the interesting shape of $\mathrm{KSPEW}$, each student is able to perform the activities of KSPEW by rotation and important use of KSPEW can increase interest and understanding of single phase electrical wiring. From past studies, (Nik Mohd Fariz bin Nik Lah, 2006) has produced teaching kits in the materials engineering drawing where subjects in his research of teachers agree that built KSPEW have learning objectives can be achieved at the end of its use. Similarly, the activities of which are in the KSPEW which teachers agree that KSPEW could improve performance as well as lesson helps teachers organize classes by means of diversification for students

\section{Impact}

Findings show that interest is at a high level, aspects of cooperation indicates the student mutual assistance while performing activities and KSPEW can help educators in the teaching process.

\section{Volume 4 Issue 12, December 2015}




\section{International Journal of Science and Research (IJSR) \\ ISSN (Online): 2319-7064}

Index Copernicus Value (2013): 6.14 | Impact Factor (2014): 5.611

\section{Scope of Future}

Based on the findings above, proposals should be dealt with by some parties to ensure the success of the practice of the use of teaching aids in education institutions :

i) The resource center in skills training institutions should be equipped with teaching aids which are frequently used by instructors in teaching a particular concept of electrical wiring.

ii) Educators should nurture the attitude of wanting to try, especially the use of methods and materials to help teach and be able to take into account various intelligence students and different learning styles.

iii) Educators improve teaching and learning activities that are student-centered, collaborative method cooperative and Constructivism.

iv) The skills training institution administrators should give full support in the implementation of various methods to focus students and help solve the problem of management workshops.

\section{References}

[1] Ahmad Rizal Madar(2006). Kajian tentang Kesan Penggunaan Koswer Terhadap Tahap Pencapaian Pelajar Berdasarkan Gaya Kognitif Field Independence-depence.

[2] Connel, W.F. (1981). Asas Pendidikan, Kuala Lumpur, Dewan Bahasa dan Pustaka

[3] Dywer, F.M (1978). Strategies For Improving Visuals Learning : A Handbook For EffectiveSelestion, Design And Use Of Visualized Materials. Pannsylvania: Learning Service, State College.

[4] Fatimah Ali (1980). Media Mudah Untuk Pengajaran. Pemilihan dan Pengeluaran. Kertas Kerja Konsep V, Persatuan suluh Budiman.

[5] Gagne, P, Holt, Rinehart dan Winston (1976) The Conditions of Learning. NY.

[6] Henry Ellington and Phil Race, (1994). Producing Teaching Materials, Kogan Page Ltd, London, Nicholas Publising Company.

[7] Ibrahim Mamat (1993). Kepimpinan Sekolah: Teori dan Praktis. Kuala Lumpur: Kumpulan Budiman Sdn. Bhd.

[8] Kamarudin Hj. Husin (1990). Kaedah Pengajaran Dan Pembelajaran Bahasa. Kuala Lumpur : Saujana

[9] Muhamad Hasan, A. R.(2000). Media Pengajaran : Penghasilan Baharu Pengajaran Berkesan. Serdang, Selangor : Universiti Putra Malaysia,

[10] Mohd Majid Konting (1994). Kaedah penyelidikan Pendidikan. Kuala Lumpur Dewan Bahasa dan Pustaka.

[11] Mok Soon Sang (2000). Pendidikan di Malaysia. Subang Jaya, Selangor: Kumpulan Budiman Sdn. Bhd.

[12] Nik Mohd Fariz bin Nik Lah (2006). Persepsi Guru Pelatih Tahun 5 Sarjana Muda TeknologiSerta Pendidikan (Awam / Elektrik / Jentera) Terhadap Penggunaan Bahan Bantu Mengajar Bagi Matapelajaran Lukisan Kejuruteraan Di Sekolah. UTM: Tesis Sarjana Muda.
[13] Omardin Ashaari (1996). Pengurusan sekolah Satu Panduan Lengkap. Kuala Lumpur: utusan Publications and Distributors Sdn. Bhd.

[14] Oodewald. P and Reimen. T (2007). Measuring Conceptual Knowledge Among NPP Maintenance Personnel - A Tool For Knowledge Management. IEEE Xplore.

[15] Rahim selamat (1990). Teknologi Sistem Pengajaran, Kuala Lumpur : Fajar Bakti Sdn. Bhd.

[16]Rosniah Mustaffa (2007). Mengadaptasikan Gaya Pembelajaran Pelajar ESL: Satu Kajian Kes Pelajar Tahun Satu, UKM.

[17] Rudin Salinger (1994). Alat Bantuan Mengajar Ringkas, Rasional, Penggunaan dan Pembinaan. Mahelah.

[18] Seidman, S.A (1986). A survey Of School Teacher Utilization Of Media. Educational Technology, Oct. 1986.

[19] Sharifah Alwiyah Alsagoff (1987). Psikologi Pendidikan I, Petaling Jaya, Logman.

[20] Tajul Ariffin Nordin dan Nor Aini Din (1992). Pendidikan dan Wawasan 2020. Kuala Lumpur: Arena Ilmu.

[21]Yeo, K.J (1986). Amalan Penggunaan Alat Bantu Mengajar Dalam Pengajaran dan Pembelajaran Di Kalangan Guru Sekolah Menengah. Tesis S. Sains (Teknologi Pendidikan) Universiti Teknologi Malaysia.

\section{Author Profile}

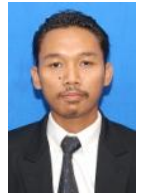

Jasman Bin Esmon received the Master of Technical and Vocational from Tun Hussein Onn University in 2014 and Degree in Electrical Engineering of Tun Hussein Onn College in 2003. Presently he is working with community college as educator. 